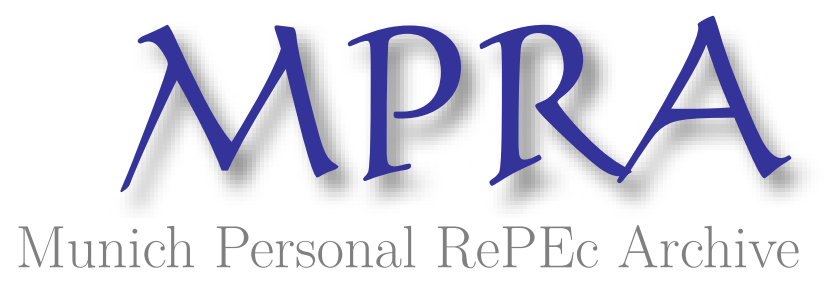

\title{
Long term funding and regulation: facilitating financial stability and development in low income developing countries
}

\author{
Marianne, Ojo \\ North West University
}

23 February 2015

Online at https://mpra.ub.uni-muenchen.de/62383/

MPRA Paper No. 62383, posted 24 Feb 2015 15:13 UTC 


\title{
Long Term Funding and Regulation: Facilitating Financial Stability and Development in Low Income Developing Countries
}

\begin{abstract}
Basic and fundamental issues which link financing and funding activities to financial regulation involve the problems of systemic risks and asymmetric information. In addition to addressing these issues, this paper will also consider other issues related to long term funding, which affect financial stability and development in Low Income Developing Countries (LIDCs) - namely inadequate regulatory frameworks, as well as constraints and accessibility to long term funding.

By considering the recent developments with the Basel framework, it will seek to illustrate, by way of reference to studies, why low income developing countries, as well as selected emerging economies are still lagging behind in terms of the implementation of regulatory standards. It will also aim to demonstrate how these countries would largely benefit from effective implementation of these standards.

Whilst aiming to facilitate means whereby sources of longer term funding could be enhanced, it will also consider the disadvantages and risks associated with longer term funding, challenges imposed by debt sustainability and propose alternative sources of funding. Transparency and disclosure, it will be highlighted, continue to generate severe obstacles to financial development and growth, as will be reflected from results of certain investigations.
\end{abstract}

Key Words: liquidity risk; long term funding; financial stability; Low Income Countries (LICs); information disclosure 


\section{Long Term Funding and Regulation: Facilitating Financial Stability and Development in Low Income Developing Countries \\ Marianne Ojo ${ }^{1}$}

\section{A Introduction}

In the opening remarks to its Report, ${ }^{2}$ the International Monetary Fund (IMF) highlights that "focal points in the Fund's engagement with small states could be the financial sector - given the challenges of small markets and limited supervisory resources and policies to enhance resilience.”

Key macroeconomic issues identified with small states, as indicated in the Report, relate to, and include the following: ${ }^{3}$

- Debt, and particularly debt sustainability and fiscal measures aimed at facilitating debt reduction;

- $\quad$ Monetary and exchange rate policies, and particularly, fixed exchange rate regimes

Even though the IMF is engaged in capacity building, which involves the provision of training activities aimed at managing macroeconomic and financial policies and enhancing their resilience to adverse shocks, ${ }^{4}$ more efforts are still needed in respect of areas relating to financial regulation and supervision.

The role of finance in job creation, growth and development within the financial sector is well documented. Even though many low income developing countries are faced with the challenges of sustaining debt levels, and even though savings should still be encouraged, long term funding is still preferable to short term funding.

\footnotetext{
${ }^{1}$ Professor, Faculty of Commerce and Administration, North-West University Email: marianneojo@hotmail.com

${ }^{2}$ See IMF, "Macroeconomic Issues in Small States and Implications For Fund Engagement”, key points section, page 2, February 202013

${ }^{3}$ see ibid at pages $23-32$

${ }^{4}$ see ibid at page 41
} 


\section{Constraints on Long Term Funding}

Whilst Basel III regulations are considered to have increased the cost of capital, many jurisdictions would still benefit from implementing and adopting such regulations. And whilst not all jurisdictions are well equipped to do so at the moment, they should be provided with incentives to do so.

In several financial institutions in Africa and South Asia, given the fact that many activities revolve round the informal sector - hence the likelihood that such activities will be subject to monitoring, enforcement and sanctions are very low, the role and importance of regulation in these jurisdictions becomes very apparent. Furthermore, in the absence of monitoring, supervision and enforcement, certain consequences, namely, undercapitalization, fraudulent practices, inefficient management and regulatory and supervisory loopholes, are likely and inevitable consequences.

The Basel Committee on Banking Supervision has recently endorsed its approval of the use of risks drivers over credit ratings. This will have considerable consequences for many jurisdictions - particularly those in South Asia where a lot of reliance is placed on information provided by credit ratings.

How are these jurisdictions to be assisted in their efforts to engage in the implementation and adoption of Basel standards which will further improve their prospects of obtaining long term funding - as well as ensuring that such a move does not present dis stabilising consequences for their economies. Should other efforts aimed at encouraging the build up of savings, rather than debt, be resorted to? How are issues relating to information asymmetries, transparency and disclosure to be facilitated in such jurisdictions?

In order to address the above questions, a body of literature relating to theories and empirical studies on financial growth and development will be considered in the ensuing section, section $\mathrm{B}$. As well as addressing the questions on the current and past literature and various perspectives shared in relation to whether or not, financial development and growth are correlated, it will also consider the impact of savings on growth and financial development. Whilst section $\mathrm{C}$ analyses and assesses the effectiveness of the implementation of Basel rules and regulation in several jurisdictions, section $\mathrm{D}$ considers the systemic impact of liquidity risks, as well as focuses on initiatives which are currently being undertaken to discourage reliance on short term funding. 


\section{B Literature Review}

Rationale for Long Term Investment

According to the report of the Group of Thirty, long-term investment is defined as:

- spending on the various types of infrastructure that, all things being equal, can expand the productive capacity of an economy. This encompasses tangible assets (such as roads, bridges, ports, machinery, factories, commercial buildings, hospitals, and new housing units) and intangible assets (such as education and research and development) that increase future prospects for innovation and competitiveness. ${ }^{5}$

The Report also highlights four principles which are considered to be vital for the ideal functioning and environment of a market in which long term finance can effectively operate. The fourth of these principles, being that: an efficient global financial system should promote economic growth through stable cross-border flows of long-term finance, supported by appropriate global regulation. ${ }^{6}$

According to Levine, the links between the functioning of the financial system and economic growth motivate research into the legal, regulatory, and policy determinants of financial development. ${ }^{7}$ Further, he accentuates links between finance and growth theory by identifying two important points, namely:

The first being that since a substantial body of accounting literature suggests that physical capital accumulation per se does not account for much of long-run economic growth and if finance is to explain economic growth, theories that describe how financial development influences resource allocation decisions in ways that foster productivity growth will be required (not directing the focus too narrowly on aggregate savings). The second being, that financial arrangements that improve resource allocation and lower risk may lower saving rates.

The impact of savings on financial growth and development is hereby emphasised.

\footnotetext{
${ }^{5}$ Group of Thirty, “Long Term Finance and Economic Growth” at page 20 Washington D.C 2013

${ }^{6}$ See ibid at page 22

${ }^{7}$ See R Levine, “Finance and Growth: Theory and Evidence” NBER Working Paper No. 10766 Sept 2004 at page 4 http://www.nber.org/papers/w10766.pdf

8 ibid at page 6
} 
Taking into account two different econometric methodologies, namely:

- cross country regressions; and

- time series regressions,

Arestis and Demetriades ${ }^{9}$ sought to demonstrate that the time series approach is more productive for the analysis involving financial growth and development.

The first limitation identified with cross country regressions is as follows: ${ }^{10}$

Whilst Arestis and Demetriades contend that they do not disagree with King and Levine's opinion ${ }^{11}$ that financial development and growth are "robustly correlated", they are not of the opinion that the question of causality "can satisfactorily addressed" in a cross- section framework.

Secondly, they argue that the cross country regressions approach can only refer to the "average effect" of a variable across countries and that whilst testing this limitation is quite difficult, since possibility of differences in causality patterns across countries is likely, such differences can be (or are "in fact") detected by time series studies. ${ }^{12}$

Carlin and Mayer ${ }^{13}$ also analyse some empirical studies involving relationships between institutional frameworks of advanced OECD countries and from their investigations, those relating to growth and development whose results are also contrasted include those relating to Rajan and Zingales ${ }^{14}$, (who examine the channel through which financial development influences growth) and Cetorelli and Gambera (who perform a similar test to the analysis carried out by Rajan and Zingales - modifying their own study by testing for the role of the structure rather than size of the banking system).$^{15}$

Whilst the analysis provided by Rajan and Zingales is considered to support the view that: ${ }^{16}$

\footnotetext{
${ }^{9}$ P Arestis and P Demetriades, “Financial Development and Economic Growth: Assessing the Evidence” The Economic Journal Volume 107 May 1997 at page 784

${ }^{10}$ see ibid at 785

${ }^{11}$ See ibid;RG King and R Levine, “Finance and Growth: Schumpeter Might Be Right” (1993) Quarterly Journal of Economics Vol 108 pp 717-37

12 P Arestis and P Demetriades, “Financial Development and Economic Growth: Assessing the Evidence” The Economic Journal Volume 107 May 1997 at page 785

${ }^{13}$ W Carlin and C Mayer, “Finance, Investment and Growth” Journal of Financial Economics 69 (2003) at page 195

${ }^{14}$ R Rajan and L Zingales, “Financial Dependence and Growth” (1998) American Economic Review (88) 559-586

${ }^{15}$ N Cetorelli and M Gambera, “Banking Market Structure, Financial Dependence and Growth: International Evidence from Industry Data” Journal of Finance (56) 617-648

${ }^{16}$ See W Carlin and C Mayer, “Finance, Investment and Growth” Journal of Financial Economics 69 (2003) at page 195
} 
- $\quad$ The quality of financial development, as measured by accounting standards, fosters growth in industries that are dependent on external finance;

the results obtained from Cetorelli and Gambera indicate that industries dependent on external finance grow faster in the presence of a concentrated banking system. ${ }^{17}$

Hence the above analyses demonstrate the impact of institutional arrangements on financial growth and development. However legal and regulatory frameworks, as well as other factors that have been highlighted under this section, also impact financial development. Using theories summarised by Allen and Gale ${ }^{18}$ and incorporated by Carlin and Mayer the importance of information disclosure is further reinforced. From the theories considered by Carlin and Mayer, ${ }^{19}$ institutional structures that are considered most relevant are information disclosure, the size and concentration of credit markets, and ownership concentration.

The first class of theories emphasizes differences in the way in which financial systems accumulate information, second set of theories involve renegotiation and the the third set of theories concerns corporate governance and commitment

Since the focus of this study includes namely, the vital role of regulation and long term finance in promoting financial stability and economic growth, the ensuing section will analyse and assess the effectiveness of the implementation of Basel rules and regulation in several jurisdictions.

\footnotetext{
${ }^{17}$ ibid;

18 F Allen and D Gale, 2000. Comparing Financial Systems. MIT, Cambridge, MA, see W Carlin and C Mayer, "Finance, Investment and Growth” Journal of Financial Economics 69 (2003) at page 192

19 ibid
} 


\section{Case Studies on Basel Framework Implementation in Selected Jurisdictions}

Based on "Five Year Average Composite Scores" obtained by Sophastienphong and Kulathunga (2010), ${ }^{20}$ which comprise of data from Afghanistan, Bangladesh, Bhutan, India, Nepal, the Maldives, Pakistan and Sri Lanka, with eight dimensions being incorporated into the study, results indicate the following:

Dimensions

i) Access to Finance

ii) Performance and Efficiency

iii) Financial stability

iv) Capital market development

v) Market concentration and competitiveness

vi) Payment systems development

vii) Savings mobilisation

viii) Corporate governance

\section{i) Access to Finance}

The Maldives performed best - in relation to Access to Finance - with Sri Lanka performing second best.

\section{ii) Performance and Efficiency}

The Maldives also performed best under this dimension - with Pakistan performing second best

\section{iii) Financial stability}

India performed best under this dimension - with Pakistan and Bhutan following each other, separated marginally in terms of their performance.

Micro economic indicators used by Sophastienphong and Kulathunga for this dimension include capital adequacy ratio, leverage ratio, gross non performing loans ratio, provisions to non performing loans ratio, liquid assets ratio, liquid assets to liability ratio.

iv) Capital market development

\footnotetext{
${ }^{20}$ K Sophastienphong, and A Kulathunga, (2010) Getting Finance in South Asia 2010 Indicators and Analysis of the Commercial Banking Sector World Bank Washington DC
} 
India performed best - with Pakistan performing second best

v) Market concentration and competitiveness

India performed best - with Bangladesh following second.

vi) Payment systems development

Sri Lanka performed best - outstandingly well - with India coming second. In comparison to the other dimensions, the margin between the leading performing country and other jurisdictions was considerably wide.

vii) Savings mobilisation

India performed best - with Bangladesh coming second

viii) Corporate governance

Pakistan performed best - with India and Sri Lanka coming jointly second

Micro economic indicators incorporated into the study include ownership structure and influence of external stakeholders, investor rights (shareholder meetings, basic ownership and voting rights), transparency and disclosure, board structure and effectiveness.

In relation to this dimension, the micro economic indicator which gave rise for concern was that relating to transparency and disclosure.

Overall, it can be ascertained that India generated the best overall performance. This is also reflected in relation the implementation of Basel regulations. According to their report, Sophastienphong and Kulathunga (2010:18) ${ }^{21}$ also highlighted the fact that whilst Afghanistan, Bhutan and the Maldives had not yet implemented Basel II - even though they were in compliance with Basel I, that Bangladesh, India, Nepal, Pakistan and Sri Lanka had adopted Basel II and were at various stages of implementation.

Further problems identified relate to discrepancies involved in the comparison of capital adequacy ratios of the countries:

\footnotetext{
${ }^{21}$ K Sophastienphong, and A Kulathunga, (2010) Getting Finance in South Asia 2010 Indicators and Analysis of the Commercial Banking Sector World Bank Washington DC page 18
} 
- Differences in the pace at which South Asian countries were progressing with the adoption of Basel II standards, along with differences in the capital guidelines adopted by each country - which have resulted in differences in the capital adequacy ratio;

- Differences in the methods used to calculate the capital charges - which have further contributed to disparities.

Is information provided through credit ratings agencies in South Asia, superior to those of micro economic indicators?

The fact that information relied on through the above micro economic indicators such as transparency and disclosure, is not very reliable does not necessarily mean that such information provided by micro economic indicators could not prove to be more superior to that provided by credit ratings agencies. Audit committees are appointed in the majority of countries which constitute the focus of the above case studies - even though according to the case study results, clarity is required as regards whether the committee chair attends shareholder meetings and whether chair is available to address questions on audit in certain jurisdictions such as Afghanistan, Bangladesh, Pakistan and Sri Lanka.

\section{Liquidity Risk Management: Financial Stability with Longer Tem Funding}

\section{The Systemic Impact of Liquidity Risks}

Basel III Liquidity Standards - The Liquidity Coverage Ratio and Net Stable Funding Ratio

The definition of liquidity, as provided by the Bank of International Settlements (BIS), is "the ability of a bank to fund increases in assets and meet obligations as they come due, without incurring unacceptable losses. The fundamental role of banks in the maturity transformation of short-term deposits into long-term loans makes banks inherently vulnerable to liquidity risk, both of an institution-specific nature and that which affects markets as a whole.”

Whilst the Liquidity Coverage Ratio (LCR)'s objective is aimed at „promoting the short-term resilience of the liquidity risk profile of banks by ensuring that banks have an adequate stock of unencumbered high quality assets (HQLA) that can be converted easily and immediately into cash“ to meet the liquidity needs of private markets for a 30 calendar day liquidity stress scenario, the Net Stable Funding Ratio (NSFR) is targeted at medium to longer term funding activities of banking institutions.

Since the Net Stable Funding Ratio is the ratio which focuses on longer term funding activities of banking institutions, efforts are being made by regulators to encourage less reliance on shorter term 
funding activities. This being particularly the case since the recent Financial Crisis has demonstrated not only that financial institutions complying with stipulated capital adequacy ratios could still face serious financial distress, but also how quickly a credit crisis could generate into one attributed to liquidity problems.

As highlighted in the introductory paragraph to this section, "The fundamental role of banks in the maturity transformation of short-term deposits into long-term loans makes banks inherently vulnerable to liquidity risk, both of an institution-specific nature and that which affects markets as a whole.”

Levine $^{22}$ argues that stock markets, financial intermediaries may also enhance liquidity, reduce liquidity risk and influence economic growth. He also makes reference to Diamond and Dybvig's (1983) model and its assumption that it is prohibitively costly to observe shocks to individuals, so it is impossible to write incentive compatible state-contingent insurance contracts. Under this assumption, he further argues that banks can offer liquid deposits to savers and undertake a mixture of liquid, low return investments to satisfy demands on deposits and illiquid, high-return investments and that through the provision of demand deposits and choosing an appropriate mixture of liquid and illiquid investments, banks are able to provide complete insurance to savers against liquidity risk while simultaneously facilitating long-run investments in high return projects.

Whilst the collaborative work undertaken by the World Bank and IMF in pooling risk activities and engaging in liquidity risk management activities are highly commended, greater efforts should also be aimed at providing LIDCs with training and support facilities in the areas of risk management and the benefits that can be derived from savings initiatives such as that proposed above. Programmes and initiatives aimed at facilitating debt sustainability are certainly needed - however greater focus on the benefits of savings and the importance of liquidity with collaborations from financial intermediaries and other organisations (not just banks), along with incentive packages to increase involvement and participation in such schemes will definitely pave way for further progressive developments. Other mediums through which investment programmes could be encouraged include the establishment of associations which are specifically directed at those who may have concerns about risky investments and hence which to invest in less risky but also high-return schemes. This might be of particular interest in those jurisdictions where no pensions schemes are provided by employers and in situations where growing concerns about future and security may be involved. Further, given cases such as Enron, and other corporate failures, the risk of investing in certain shares and stocks has discouraged many from investing their future in such organisations.

${ }^{22}$ R Levine, “Finance and Growth: Theory and Evidence” NBER Working Paper No. 10766 Sept 2004 at page 20 


\section{Discouraging Incentives Towards Short-Tem Funding: Global Developments Aimed at Fostering Financial Stability}

According to Valladares, the liquidity standard is divided into short and long term buffers - a means of ensuring that banks are liquid. ${ }^{23}$ The focus on financial stability through incentives aimed at placing less reliance on short term funding is also illustrated through recent proposals and rules introduced by the Federal Reserve in the efforts to address further issues relating to calibration. The issue of calibration between the risk based capital adequacy framework and the Basel leverage framework, relates to its potential source of undercapitalisation of financial and non financial institutions.

With respect to the calibration of surcharges, it was highlighted that such calibration would: ${ }^{24}$

- generally be higher than those applicable to the eight covered U.S. banks under the international standard, and the formula by which applicable surcharges would be calculated would directly take into account the reliance of each firm on short-term wholesale funding.

Hence the efforts being made to discourage reliance on short-term funding is demonstrated. These steps and initiatives also demonstrate commitment towards towards the enhancement of the micro-prudential framework whereby liquidity risk management efforts would be facilitated - as well as further consolidation of the macro-prudential outlay which embodies Basel III.

Reasons highlighted for adopting such a different approach as indicated in the statement are as follows: ${ }^{25}$

with respect to calibration, surcharge levels for most of the eight banks would be higher under the proposal than those required by the Basel standard, and likely meaningfully higher for some of the firms. The approach to calibration being developed in cooperation with other Basel Committee members as a means of determining the additional capital necessary to equalize the probable systemic impact from the failure of a systemically important bank as compared to the probable systemic impact from the failure of a large, but not systemically important, bank holding company.

- Fact that reliance on short-term wholesale funding is among the more important determinants of the potential impact of the distress or failure of a systemically important financial firm on the broader

\footnotetext{
${ }^{23}$ MR Valladares “What Awaits Banks After the Leverage Ratio?” http://dealbook.nytimes.com/2014/04/09/what-awaits-banks-after-the-leverage-ratio

${ }^{24}$ Tarullo, “ Opening Statement by Governor Daniel K. Tarullo before Federal Reserve Board” http://www.federalreserve.gov/newsevents/press/bcreg/tarullo-statement-20141209.htm

${ }^{25}$ ibid
} 
financial system and that the surcharge formula developed by the Basel Committee does not directly take into account reliance on short-term wholesale funding.

- Inclusion of reliance on short-term wholesale funding as one of five factors in the systemic significance formula is intended principally as a means for assuring the resilience of large firms that are in fact dependent on such funding.

\section{E Conclusion}

\section{Regulatory Incentives to Be Introduced in LIDCs: A Collaborative Effort Between Regulatory, Accounting and International Organisations}

Having emphasised the importance of information disclosure, the role of Basel regulations, and particularly that of the Third Pillar of Basel II, namely, market discipline becomes even more apparent. Information disclosure is also a very fundamental component of financial reporting hence the role of regulatory as well as accounting standard setting authorities in effectively collaborating to harmonise, as well as facilitate the goals of market discipline are evident.

The focus on the Third Pillar of Basel II is not just relevant to all LIDCs or the jurisdictions that have been considered in this study, but is also relevant to advanced economies across the globe. As well as the goals of enhanced disclosure, which can be facilitated through consistency, comparability and simplicity, enhanced disclosure could be promoted through financial reporting channels and the education of users of financial statements - particularly those users who have less expertise at interpreting certain terms and concepts used within the reporting framework.

A recurring challenge for rules introduced through Basel, and of notable significance, the Basel III leverage ratios, relates to the inconsistencies in application through the introduction of supplementary leverage ratios and enhanced supplementary ratios - this also partly being attributed to differences in accounting policies and frameworks. Such "inconsistencies" are aimed at providing a more balanced and realistic application of the rules - given jurisdictional specific needs and more balance would even be provided if accounting and regulatory standard setters, as well as international organisations such as the IMF and World Bank, could collaborate at a greater level than is the case presently. 


\section{References}

Amo-Yartey, C., M. Narita, G. Nicholls, J. Okwuokei, A. Peter, and T. Turner-Jones, 2012, 'The Challenges of Fiscal Consolidation and Debt Reduction in the Caribbean,” IMF Working Paper 12/276 (Washington: International Monetary Fund).

Arestis P and Demetriades P, "Financial Development and Economic Growth: Assessing the Evidence” The Economic Journal Volume 107 May 1997

Basel Committee on Banking Supervision, Discussion Paper 'The Regulatory Framework: Balancing Risk Sensitivity, Simplicity and Comparability“ July 2013 Bank for International Settlements Publications Basel Committee on Banking Supervision, 'Capital Requirements and Bank Behaviour: The Impact of the Basel Accord' Basel Committee on Banking Supervision Working Papers April 1999

Basel Committee on Banking Supervision, 'Consultative Paper on a New Capital Adequacy Framework' 3rd June 1999 http://www.bis.org/press/p990603.htm

Carlin W and Mayer C, "Finance, Investment and Growth” Journal of Financial Economics 69 (2003) at pages 191-226

Cetorelli N and Gambera M, "Banking Market Structure, Financial Dependence and Growth: International Evidence from Industry Data” Journal of Finance (56) 617-648

Financial Stability Board, Update of Group of Global Systemically Important Banks (G-SIBs) (Nov. 1, 2012) http:/www.financialstabilityboard.org/publications/r 121031ac.pdf

Group of Thirty, “Long Term Finance and Economic Growth” Washington D.C 2013

King RG and Levine R, "Finance and Growth: Schumpeter Might Be Right” (1993) Quarterly Journal of Economics Vol 108 pp 717-37

Levine R, "Finance and Growth: Theory and Evidence” NBER Working Paper No. 10766 Sept 2004 at page 4 http:/www.nber.org/papers/w10766.pdf

Medina-Cas, S. and R. Ota, 2008, "Big Government, High Debt, and Fiscal Adjustment in Small States,” IMF Working Paper 08/39 (Washington: International Monetary Fund). 
Ojo, M Basel II and the Capital Requirements Directive: Responding to the 2008/09 Financial Crisis (September 2009)

Ojo, M Basel III and Responding to the Recent Financial Crisis(September 2010

Ojo, M Preparing for Basel IV (Whilst Commending Basel III Part II) (January 2011) Paper presented at the 2011 INFINITI Conference on International Finance, 13 - 14 June 2011, Trinity College Dublin (the 9th INFINITI Conference on International Finance) 13th \& 14th June 2011“Institutions, Actors and International Finance”.

Rajan R and Zingales L, “Financial Dependence and Growth” (1998) American Economic Review (88) $559-586$

Sophastienphong, K. and Kulathunga, A. (2010) Getting Finance in South Asia 2010 Indicators and Analysis of the Commercial Banking Sector World Bank Washington DC

Tarullo D , “ Opening Statement by Governor Daniel K. Tarullo before Federal Reserve Board” http:/www.federalreserve.gov/newsevents/press/bcreg/tarullo-statement-20141209.htm

United Nations (2000), "Microfinance in Africa: Combining the Best Practices of Traditional and Modern Finance Approached Towards Poverty Eradication”, United Nations Economic Commission for Africa. http://www.un.org/esa/africa/microfinanceinafrica.pdf Accessed 28th August 2014

Valladares MR“What Awaits Banks After the Leverage Ratio?”

http://dealbook.nytimes.com/2014/04/09/what-awaits-banks-after-the-leverage-ratio 